\title{
Anal Cancer pM1 TNM Finding v6 and v7
}

National Cancer Institute

\section{Source}

National Cancer Institute. Anal Cancer pM1 TNM Finding v6 and v7. NCI Thesaurus. Code C67551.

Anal cancer with distant metastasis. (from AJCC 6th and 7th Eds.) 